\title{
PERAN ORANG TUA DALAM MENDAMPINGI PESERTA DIDIK BELAJAR DI MASA PANDEMI COVID-19 PADA SD ISLAM NURUL IHSAN PALANGKARAYA
}

\author{
Rita Rahmaniati, Neng Mariani, Dwi Sari Usop \\ Universitas Muhammadiyah Palangkaraya, RTA Milono St. Km. 1,5, Palangka Raya, Indonesia \\ rahmaniatirita@gmail.com
}

\begin{abstract}
ABSTRAK
Penelitian ini bertujuan untuk mengetahui peran orang tua dalam mendampingi peserta didik pada saat pembelajaran dari dimasa pandemi covid 19. Metode penelitian yang digunakan dalam penelitian ini adalah metode penelitian kualitatif. Subjek penelitian ini adalah Guru kelas V, orang tua dan peserta didik kelas V di SD Islam Nurul Ihsan. Adapun teknik pengumpulan data yang digunakan adalah observasi, wawancara, dan dokumentasi. Prosedur analisis data menggunakan tahapan yang terdiri dari Pengumpulan Data, Reduksi Data, Penyajian Data, dan Penarikan Kesimpulan. Hasil penelitian menunjukkan bahwa orang tua peserta didik kelas V SD Islam Nurul Iiihsan Palangkaraya mengalami kesulitan dalam mendampingi peserta didik belajar dirumah pada masa pandemi covid-19 karena factor dalam dan factor luar. Faktor dalam yaitu 1) kurangnya pengetahuan dan pendidikan orang tua, 2) minimnya waktu yang dimiliki orang tua untuk mendampingi dan mengawasi peserta didik 3) kurangnya komunikasi antara orang tua dan peserta didik 4) orang tua kurang mampu memberikan motivasi sedangkan faktor dari luar yaitu factor guru, yakni 1) kurang maksimalnya penjelasan guru terhadap materi dan 2) tingkat ekonomi keluarga. Rekomendasi dari penelitian adalah adalah guru dan kepala Sekolah hendaknya membekali orang tua untuk mendampingi belajar anak di rumah melalui kegiatan pelatihan pendampingan pembelajaran Daring bagi orangtua.
\end{abstract}

Kata kunci: Peran orang tua; Pembelajaran Daring; Sekolah Dasar; Pandemi Covid-19

\begin{abstract}
This study aims to determine the role of parents in assisting students during learning from the covid 19 pandemic. The research method used in this study is a qualitative research method. The subjects of this study were fifth grade teachers, parents and fifth grade students at Nurul Ihsan Islamic Elementary School. The data collection techniques used are observation, interviews, and documentation. The data analysis procedure uses stages consisting of Data Collection, Data Reduction, Data Presentation, and Drawing Conclusions. The results showed that parents of fifth grade students at the Islamic Elementary School Nurul Iiihsan Palangkaraya had difficulties in assisting students to study at home during the COVID-19 pandemic due to internal and external factors. Internal factors are 1) lack of parental knowledge and education, 2) lack of time for parents to accompany and supervise students 3) lack of communication between parents and students 4) parents are less able to provide motivation while external factors are factors teachers, namely 1) the teacher's explanation of the material is less than optimal and 2) the economic level of the family. The recommendation from the research is that teachers and principals should equip parents to assist their children's learning at home through online learning mentoring training activities for parents.
\end{abstract}

Keywords: Parents Role; Online Learning; Elementary School;Covid-19 Pandemic.

Dipublikasikan Oleh :

UPT Publikasi dan Pengelolaan Jurnal

Universitas Islam Kalimantan Muhammad Arsyad Al-Banjari Banjarmasin 
Rita Rahmaniati, Neng Mariani, Dwi Sari Usop

Jurnal Bimbingan dan Konseling Ar-Rahman

Volume 7, Nomor 2, Tahun 2021

e-ISSN 2477-6300

\section{PENDAHULUAN}

Pemerintah telah mengalihkan kegiatan pembelajaran dari sekolah kerumah masingmasing siswa sebagai bagian dari upaya menghentikan penyebaran virus corona (Covid19). Agar tidak disalah artikan sebagai hari libur, maka proses pembelajaran dilakukan secara daring. Penggunaan media pembelajaran dalam hal belajar mengajar merupakan salah satu upaya untuk meningkatkan evektivitas serta kualitas proses pembelajaran yang pada akhirnya dapat meningkatkan kualitas hasil belajar peserta didik. Pembelajaran daring adalah pembelajaran yang mampu mempertemukan mahasiswa dan dosen untuk melaksanakan interaksi pembelajaran dengan bantuan internet (Kuntarto, E. (2017). Pada tataran pelaksanaanya pembelajaran daring memerlukan dukungan perangkat- perangkat mobile seperti smarphone atau telepon adroid, laptop, komputer, tablet, dan iphone yang dapat dipergunakan untuk mengakses informasi kapan saja dan dimana saja (Gikas \& Grant, 2013). Perguruan tinggi pada masa WFH perlu melaksanakan penguatan pembelajaran secara daring (Darmalaksana, 2020). Pembelajaran secara daring telah menjadi tuntutan dunia pendidikan sejak beberapa tahun terakhir $(\mathrm{He}$, Xu, \& Kruck, 2014). Pembelajaran daring dibutuhkan dalam pembelajaran di era revolusi industri 4.0 (Pangondian, R. A., Santosa, P. I., \& Nugroho, E., 2019).

Penggunaan media pembelajaran daring bertujuan memberikan layanan pembelajaran bermutu dalam jaringan (daring) yang bersifat terbuka untuk menjangkau peminat yang lebih banyak daln lebih luas. Karakteristik dari pembelajaran daring yaitu memungkinkan peserta didik belajar tanpa harus pergi ke ruang kelas, dan pembelajaran dapat dijadwalkan sesuai kesepakatan antara instruktur dan peserta didik, atau peserta didik dapat menentukan sendiri waktu belajar yang diinginkan. Menurut Clark dan Mayer (2011), karakteristik belajar daring yaitu; 1) Pembelajaran berbasis daring harus memiliki dua unsur penting yaitu informasi dan metode pengajaran yang memudahkan orang untuk memahami konten pelajaran 2) Pembelajaran berbasis daring dilakukan melalui komputer menggunakan tulisan, suara, atau gambar seperti ilustrasi, photo, animasi, dan video. 3) Pembelajaran berbasis daring diperuntukkan untuk membantu pendidik mengajar seorang peserta didik secara objektif.

Penelitian Irfan Nurkholis (2021)

Pembelajaran daring lebih memiliki kelebihan di bandingkan kekurangannya ditinjau dari aspek aspek:

1. Aspek Sarana dan Prasarana, aspek Sarana dan Prasarana mendapat nilai presentase kelebihan proses pembelajaran secara daring sebanyak $80,24 \%$ dan kekurangan pada proses pembelajaran secara daring sebanyak $70,74 \%$.

2. Aspek Sumber Daya Manusia, aspek Sumber Daya Manusia mendapat nilai presentase kelebihan proses pembelajaran secara daring sebanyak $82,24 \%$ dan kekurangan pada proses pembelajaran secara daring sebanyak $80,02 \%$.

3. Aspek Karakteristik Pengajar dan Siswa, Aspek Karakteristik Pengajar dan Siswa mendapat nilai presentase kelebihan proses pembelajaran secara daring sebanyak $75,72 \%$ dan kekurangan pada proses pembelajaran secara daring sebanyak $72,62 \%$.

4. Aspek Jaringan (Network) dan Kuota, aspek Jaringan (Network) dan Kuota mendapat nilai presentase kelebihan proses pembelajaran secara daring sebanyak $84,28 \%$ dan kekurangan pada proses pembelajaran secara daring sebanyak $76,23 \%$.

5. Aspek Kebijakan Pemerintah, aspek Kebijakan Pemerintah mendapat nilai presentase kelebihan proses pembelajaran secara daring sebanyak $77,45 \%$ dan kekurangan pada proses pembelajaran secara daring sebanyak $75,22 \%$.

Pembelajaran daring dilakukan peserta didik di rumah menuntut lebih peran orang tua untuk mendampingi anaknya belajar. Peran orang tua merupakan peran yang memiliki andil dalam mendukung keberhasilan anaknya terutama dalam meningkatkan motivasi belajar peserta didik. Orang tua berperan mengupayakan perkembangan potensi peserta didik, baik potensi efektif, kognitif, maupun psikomotorik. Motivasi yang di berikan orang tua tidak sebatas ucapan, tetapi juga bentuk lain sehingga mampu membangkitkan semangat dan motivsi belajar peserta didik. Beberapa peran orang tua dalam meningkatkan motivasi belajar peserta didik yaitu terlibat dalam kegiatan belajar peserta didik, memperhatikan kondisi peseta didik baik fisik maupun psikis, memahami dan mengatasi kesulitan belajar peserta didik, dan memberikan fasilitas belajar peserta didik.

Menurut Muthmainnah (2012) peran dan tanggung jawab orang tua dalam proses pembelajaran peserta didik yaitu dengan: 
Rita Rahmaniati, Neng Mariani, Dwi Sari Usop Jurnal Bimbingan dan Konseling Ar-Rahman

Volume 7, Nomor 2, Tahun 2021

e-ISSN 2477-6300

1. Mendampingi. Orang tua yang menghabiskan sebagian besar waktunya untuk bekerja, sehingga hanya memiliki sedikit waktu bertemu dan berkumpul dengan keluarga. Meskipun hanya dengan waktu yang sedikit, namun orang tua bisa memberikan perhatian yang berkualitas dengan fokus menemani peserta didik dan menyediakan fasilitas guna menunjang proses pembelajaran peserta didik selama berada dirumah.

2. Menjalin komunikasi. Komunikasi menjadi hal penting dalam hubungan orang tua dan peserta didik karena komunikasi merupakan jembatan yang menghubungkan keinginan, harapan dan respon masing-masing pihak. Melalui komunikasi, orang tua dapat menyampaikan harapan, masukan dan dukungan pada peserta didik. Begitu pula sebaliknya, anak dapat bercerita dan menyampaikan pendapatnya. Komunikasi yang diwarnai dengan keterbukaan dan tujuan yang baik dapat membuat suasana yang hangat dan nyaman dalam kehidupan keluarga.

3. Mengawasi. Pengawasan mutlak diberikan pada anak agar anak tetap dapat dikontrol dan diarahkan. Tentunya pengawasan yang dimaksud bukan berarti dengan memata-matai dan main curiga. Tetapi pengawasan yang dibangun dengan dasar komunikasi dan keterbukaan. Orang tua perlu secara langsung dan tidak langsung untuk mengamati dengan siapa dan apa yang dilakukan oleh anak, sehinga dapat meminimalisir dampak pengaruh negatif pada anak.

4. Mendorong atau memberikan motivasi.

Motivasi bisa muncul dari diri individu (internal) maupun dari luar individu (eksternal). Setiap individu merasa senang apabila diberikan penghargaan dan dukungan atau motivasi. Motivasi menjadikan individu menjadi semangat dalam mencapai tujuan. Motivasi diberikan agar peserta didik selalu berusaha mempertahankan dan meningkatkan apa yang sudah dicapai.

5. Mengarahkan. Orang tua memiliki posisi strategis dalam membantu agar peserta didik memiliki dan

\begin{abstract}
mengembangkan dasar-dasar disiplin diri.

Kenyataannya tidak semua orangtua dapat melaksanakan perannya dalam mendampingi anak-anaknya dalam belajar. Berdasrkan observasi awal di SD Islam Nurul Ihsan Kota Palangkaraya, kebanyakan orang tua peserta didik mengeluhkan bahwa dirinya keteteran dan sulit sekali membimbing peserta didik dalam hal pembelajaran. Selama ini orang tau memberikan tanggung jawab pendidikan peserta didik hanya kepada guru disekolah. Dikarenakan melihat kondisi sekarang orang tua memiliki peran ganda dalam proses pembelajaran daring di rumah. Selain tanggung jawab mendidik anak, orang tua dituntut mendampingi peserta didik belajar daring dirumah sebagai ganti pembelajaran tatap muka. Orang tua sibuk dengan pekerjaannya sehingga lupa dan tidak memperhatikan perannya dalam mendidik peserta didik, atau orang tua yang benar-benar tidak memahami dan menyadari perannya sehingga mereka cendrung menganggap bahwa tugas pendidikan sepenuhnya diserahkan pada guru disekolah.

Berdasarkan fenomena diatas maka peneliti tertarik untuk mengangkat judul "Peran Orang Tua Dalam Mendampingi Anak Belajar Pada Masa Pandemi di SD Islam Nurul Ihsan Kota Palangkaraya Tahun Ajaran 2020/2021”.
\end{abstract}

\section{METODE}

Tempat penelitian ini dilakukan di SD Islam Nurul Ihsan Palangkaraya, yang berlokasi di Jl. Dr. Murjani, Kelurahan Pahandut, kecematan Pahandut, Kota Palangkaraya Provinsi Kalimantan Tengah. Penelitian ini dilaksanakan pada bulan April 2021- Juni 2021. Pendekatan yang digunakan adalah pendekatan kualitatif. Pendekatan kualitatif digunakan untuk mendeskripsikan peran orangtua dalam mendampingi peserta didik belajar daring pada masa Pandemi. Subjek penelitian ini adalah 1 orang guru kelas $\mathrm{V}, 5$ orang peserta didik dan 5 orang tua peserta didik kelas V SD Islam Nurul Ihsan Palangkaraya. Teknik pengumpulan data dalam penelitian ini yaitu observasi, wawancara dan dokumentasi. Tahapan penelitian kualitatif ini yaitu observasi, pengamatan terhadap masalah yang menjadi sumbernya. Instrumen yang digunakan dalam penelitian ini berupa lembar observasi dan kisi-kisi wawancara dengan sumber data. Teknik analisis data yang digunakan melalui reduksi data, penyajian data, dan penarikan kesimpulan. 


\section{HASIL DAN PEMBAHASAN}

Peran orang tua dalam mendampingi peserta didik belajar dirumah pada masa pandemi covid-19 di SD Islam Nurul Ihsan Palangkaraya:

\section{Observasi Pendidik dan Peserta Didik}

Temuan peneliti ini didapat berdasarkan hasil observasi Pelaksanaan pembelajaran pada kelas V SD Islam Nurul Ihsan pada pendidik dan Peserta Didik, disajikan pada table berikut:

Tabel 1. Hasil Observasi Peran Orang Tua Dalam Mendampingi Peserta Didik Belajar di Rumah Pada Masa Pandemi Pada Kelas V

\begin{tabular}{lll}
\hline $\begin{array}{l}\text { Objek Yang } \\
\text { Diamati }\end{array}$ & \multicolumn{1}{c}{ Keserta didik } & \multicolumn{1}{c}{ Orang tua } \\
\hline Mendampingi & $\begin{array}{l}\text { Beberapa peserta didik mengatakan } \\
\text { bahwa jarang mendapat dampingan } \\
\text { dari orang tua pada saat pembelajaran } \\
\text { dirumah. }\end{array}$ & $\begin{array}{l}\text { Orang tua terlalu sibuk bekerja } \\
\text { hingga jarang memiliki waktu untuk } \\
\text { menemani dan mendampingi peserta } \\
\text { didik belajar. }\end{array}$ \\
$\begin{array}{l}\text { Kurangnya komunikasi antara peserta } \\
\text { Menjalin }\end{array}$ & $\begin{array}{l}\text { Kurangnya perhatian yang diberikan } \\
\text { orang tua pada peserta didik } \\
\text { kemunikasi }\end{array}$ & $\begin{array}{l}\text { ketika adanya tugas dari sekolah saja. } \\
\text { membuat hubungannya keduanya }\end{array}$ \\
tidak terlalu dekat.
\end{tabular}

Berdasarkan tabel diatas dari hasil observasi dapat dianalisis tentang peran orang tua dalam mendampingi peserta didik belajar dirumah pada masa pandemi covid-19 pandemi di kelas V SD Islam Nurul Ihsan Palangkaraya yaitu dari ke lima poin tersebut muncul semuanya, tetapi poin-poin yang lebih menonjol yaitu poin 1, 4, dan 5. Kemunculan poin-poin tersebut oleh beberapa faktor baik dari orang tua ataupun dari luar. Faktor dari orang tua seperti pemahaman orang tua yang kurang, dan faktor dari luar seperti penjelasan guru yang kurang maksimal.

Hasil Wawancara Orangtua, Peserta Didik dan Pendidik
Hasil Wawancara Orangtua, Peserta Didik dan Pendidik diperoleh hasil:

1. Peran Orang Tua Dalam Mendampingi Pada saat dirumah beberapa orang tua mengalami kesulitan dalam membimbing peserta didik dan apakah orang tua mendampingi peserta didik dengan baik. Hal tersebut seperti yang di katakan oleh peserta didik yaitu :

"Pada saat belajar dirumah terkadang orang tua membantu dan mendampingi saya untuk menjelaskan materi yang belum saya pahami, dengan didampingi orang tua saya lebih mudah memahami pemblejaran yang sulit." 
orang tua yaitu :

Diperkuat dengan pernyataan

"Ketika peserta didik belajar di rumah saya membantu peserta didik jika belum memahami pembelajaran yang di sampaikan oleh guru secara daring."

Peran orangtua dalam mendampingi anak di masa pandemic dengan menggunakan model belajar daring di SD Islam Nurul Ihsan Palangkaraya masih belum maksimal. Sebanyak 5 peserta didik ditemukan kurang mendapatkan bimbingan dari orang tua pada saat proses pembelajaran dirumah, hal ini berdampak pada hasil belajar peserta didik rendah, Orang tua yang bekerja/ berjualan punya sedikit waktu untuk bisa mendampingi peserta didik, hampir semua orang tua tidak punya inisiatif untuk mencarikan pendamping pengganti untuk dapat menemani peserta didik belajar dirumah. Ditambah lagi penyampaian materi yang dilakukan oleh guru kurang jelas membuat peserta semakin merasa kurang mendapatkan materi yang maksimal. Hal inilah yang dianggap pembelajaran kurang efektif, orang tua juga kesulitan memahami materi yang diberikan guru. Menurut Muthmainnah (2012) peran dan tanggung jawab orang tua dalam mendampingi proses pembelajaran peserta didik. Orang tua yang menghabiskan sebagian besar waktunya untuk bekerja, sehingga hanya memiliki sedikit waktu bertemu dan berkumpul dengan keluarga. Meskipun hanya dengan waktu yang sedikit, namun orang tua bisa memberikan perhatian yang berkualitas dengan fokus menemani peserta didik dan menyediakan fasilitas guna menunjang proses pembelajaran peserta didik selama berada dirumah.

2. Menjalin Komunikasi

Dalam menjalin komunikasi antara guru dan orang tua peserta didik. Seperti yang dikatakan oleh peserta didik bahwa :

"Kurangnya bimbingan dengan orang tua membuat membuat peserta didik sulit menjalin komunikasi yang baik karena kesibukan orang tua"

Diperkuat dengan pernyataan orang tua bahwa :

"Kesibukan bekerja karena tuntutan keluarga membuat saya sebagai orang tua merasa mengalami kesulitan dalam mendampingi dan kurangnya komunikasi antara orang tua dan peserta didik dirumah"

Guru kelas mengatakan bahwa:

"Menjalin komunikasi antara guru dan orang tua peserta didik melalui rapat evaluasi yang dilakukan dengan sistem daring ataupun luring hal ini dilakukan agar komunikasi antara guru, orang tua peserta didik semakin erat dan melihat partisipasi orang tua terhadap pendidikan peningkatan prestasi belajar peserta didik dalam proses pembelajarannya selama masa pandemi disekolah tersebut."

Orangtua (Ibu dan ayah) keduanya bekerja diluar rumah, sangat minin menjalin komunikasi dengan peserta didik. Sekedar menanyakan perolehan nilai peserta didik terkadang tidak sempat, apalagi menjalin komunikasi yang lebih intensif. Padahal komunikasi sangat penting dilakukan pada saat masa pandemi apalagi ketika proses pembelajaran daring, karena waktu peserta didik lebih banyak dirumah, bimbingan guru yang kurang dan sumber informasi lainnya terbatas. Hubungan komunikasi yang baik antara orang tua dan peserta didik sangat dibutuhkan oleh peserta didik demi kelangsungan proses pembelajaran peserta didik dirumah. Kenyataannya komunikasi antara peserta didik dan orang tua kurang erat hal inilah yang membuat peserta didik merasa kesulitan dalam proses pembelajaran, kebingungan dalam meminta bantuan ketika ada tugas ataupun materi pembelajaran yang kurang dipahami. Akibatnya peserta didik mengerjakan tugas seadanya, cenderung asal asalan agar dapat dikatakan sudah 
mengumpulkan tugas yang diberikan guru. Peran komunikasi orangtua di SD Islam Nurul Ihsan Palangkaraya juga belum maksimal, Kebanyakan orangtua masih belum menyadari betapa pentingnya komunikasi dengan peserta didik saat berada dirumah. Kebanyakan orangtua mementingkan mencari nafkah keluarga untuk memenuhi kebutuhan. Padahal mau tidak mau, orangtua pada masa pandemic seperti ini berperan menjadi guru di rumah yang tidak hanya mengajari adab dan akhlah tetapi juga berkaitan dengan materi pelajaran.

\section{Mengawasi}

Peserta didik tidak jarang mendapat pengawasan dari orang tua selama melakukan pembelajaran dirumah. Seperti yang dikatakan oleh peserta didik bahwa:

"Pada saat proses pembelajaran dirumah orang tua saya tidak punya waktu untuk mengawasi proses pembelajaran sehingga saya mengalami kesulitan dalam mengikuti proses pembelajaran selama dirumah"

Hal ini dikuatkan lagi oleh pernyataan orang tua bahwa:

"Sebagai orang tua saya mengalami kesulitan dalam meluangkan waktu untuk mengawasi peserta didik belajar dirumah, hal ini terjadi karena tuntutan pekerjaan sehingga sulitnya meluangkan waktu untuk mendampingi serta mengawasi peserta didik belajar".

Dalam hal ini guru kelas menyatakan bahwa:

"Proses pembelajaran daring tidak mudah bagi guru untuk menilai hasil dari pembelajaran karena guru juga memerlukan proses pembelajaran peserta didik oleh karena itu guru sulit dalam melihat bagaimana pengawasan dan tingkah laku peserta didik selama adanya pembelajaran yang dilakukan secara daring"

Pembelajaran daring di masa Pandemi menuntut peserta didik menggunakan teknologi seperti hp android, laptop dan media sosial lainnya. Hal ini memudahkan peserta didik dalam proses belajar daring melalui dunia maya. Namun disisi lain, teknologi informasi yang digunakan peserta didik dapat berdampak negatif jika kurang pengawasan dari orangtua. Beberapa peserta didik yang belajar menggunakan internet dan youtube, setelah pembelajaran justru menggunakannya untuk bermain game dan menonton hiburan. Hal ini perlu menjadi perhatian untuk orangtua dalam mengawasi belajar peserta didik untuk menghindarkan sesuatu yang tidak diinginkan. Kenyataannya, orangtua peserta didik di SD Islam Nurul Ihsan Palangkaraya belum dapat mengawasi anak-anaknya dalam belajar, sehingga waktu untuk belajar dan menonton hiburan tidak berimbang, sehingga berpotensi untuk penyalahgunaan tontonan. Tidak semua orangtua memiliki kemampuan menyetting andrioidnya pada tontonan sesuai dengan umur anak, bahkan anak-anak lebih melek teknologi dibandingkan orangtuanya. Namun demikian, orangtua tetap harus mengawasi anak dalam belajar, sekecil apapun bentuk pengawasannya tetap diperlukan, sebagai bentuk bahwa orangtua memberikan perhatian dan pengawasan. Mengawasi peserta didik bukan berarti memata-matai akan tetapi pada dasanya orang tua lebih memberikan perhatian dan rasa tanggng jawabnya sebagai orang tua dalam membimbing peserta didik belajar dirumah. Slain itu orangtua juga perlu mengawasi proses pengumpulan tugas yang di kirim peserta didik ke gurunya, apakah benarbenar sudah terkirim ataukah belum terkirim sesuai dengan waktu yang telah ditentukan.

4. Mendorong dan memberikan Motivasi

Peserta didik yang menyatakan bahwa tidak banyak peserta didik yang mendapat motivasi dari orang disekeliling termasuk orang tua. Menurut peserta didik bahwa:

"Kurangnya perhatian dan bimbingan orang tua mebuat peserta didik mengalami kendala dalam pembelajaran hal ini juga disebabkan oleh kurangnya 
motivasi yang di berikan oleh orang tua kepada peserta didik"

Hal ini diperkuat dengan pernyataan orang tua bahwa :

"Kurangnya perhatian serta motivasi yang diberikan pada pesarta didik membuat peserta didik kurang bersemangat dalam mengikuti proses pembelajaran dan pada akhirnya mendapat nilai yang kurang baik" bahwa :

Dalam hal ini guru menyatakan

"Kurangnya komunikasi, bimbingan serta dukungan yang diberikan oleh orang tua dapat menghambat atau memperlambat peserta didik memahami pembelajaran pada saat melakukan pembelajaran dirumah, ditambah lagi ketika penjelasan guru kurang jelas. Oleh karena itu perlunya peran orang tua dalam mendukung guru untuk memperhatikan peserta didik. "

Perhatian serta dorongan dari orangtua membuat peserta didik lebih bersemangat dalam mengikuti proses pembelajarannya. Tidak adanya motivasi yang diberikan orang tua membuat peserta didik sering bermalasmalasan dalam mengikuti pembelajaran ataupun mengerjakan tugasnya. Namun sayangnya, di SD Islam Nurul Ihsan Palangkaraya kebanyakan orangtua menyerahkan Pendidikan anaknya pada sekolah, bahwa anak belajar itu tanggung jawab sekolah. Kebanyakan orang tua justru banyak mengeluh dalam mendampingi anak belajar, seharunya memberikan dorongan dan motivasi sehingga anak lebih giat dan lebih mandiri. Adapun pemberian motivasi dan dorongan yang dapat diberikan orangtua saat belajar dirumah melalui pujian terhadap tugas yang telah dikerjakan anak secara mandiri maupun kelompok, memberikan hadiah kecil kepada anak atau sekedar melihat hasil pekerjaan anak dalam belajar dan memberikan komentar positif.

5. Mengarahkan dan memberikan contoh
Mengarahlan dan memberikan contoh untuk anak belum maksimal oleh orangtua dinyatakan oleh peserta didik bahwa:

"Kesulitan yang saya hadapi pada saat mendapat tugas dari guru yaitu penjelasan guru yang kurang jelas kemudian orang tua tidak mampu mengarahkan dan memberikan contoh karena tidak memahami materi pembelajaran"

Dikuatkan oleh pernyataan orang tua bahwa :

"keterbatasan pendidikan orang tua menjadi faktor penghambat untuk mendampingi peserta didik mengerjakan ttugas karena tidak mampu mengarahkan dan memberi contoh pada peserta didik dirumah"

Pembelajaran dirumah, menggunakan teknologi informasi perlu arahan dari orangtua. Kenyataannnya di SD Islam Nurul Ihsan Palangkaraya orangtua belum dapat maksimal dalam mengarahkan anak belajar, diketahui hal tersebut karena kurangnya pengetahuan orangtua terhadap materi pelahjaran dan waktu orangtua untuk mengarahkan. Bahkan sebagian orangtua kurang sabar dalam mengarahkan anaknya belajar. Ketidak sabaran adalah salah satu kesalahan dalam mendidik peserta didik, dan tenyata masih banyak orang tua yang kurang sabar dalam mendidik peserta didik, hal ini tentunya sangat disayangkan karena orang tua mempunyai kewajiban untuk membentuk, mengarahkan, membmbing, dan mendidik peserta didik dengan penuh kesabaran (Iriani, 2014). Orang tua harus menjadi figur dalam memberi kesabaran pada peserta didik, hal lain menunjukkan bahwa ternyata orang tua juga sudah merasa jenuh dengan pembelajaran yang dilakukan dirumah hal itu memicu ketidaksabaran orang tua dalam menemani peserta didik belajar dan bermain (Tabiin, 2020).

Menurut Irhamna (2016) kendala yang yang di hadapi oleh orang tua dalam melakukan kedisiplinan belajar pada peserta didik di rumah, diantaranya yaitu kurangnya waktu bersama peserta didik akibat kesibukan pekerjaan di luar rumah, kurangnya pengetahuan mendidik peserta didik tentang agama, pergaulan peserta didik

Dipublikasikan Oleh : 
Rita Rahmaniati, Neng Mariani, Dwi Sari Usop

Jurnal Bimbingan dan Konseling Ar-Rahman

Volume 7, Nomor 2, Tahun 2021

e-ISSN 2477-6300

dalam lingkungan dan kesadaran peserta didik itu sendiri yang belum maksimal.

Temuan di SD Islam Ihsan Palangkaraya tentang peran orangtua dalam mendampingi anak dalam pembelajaran daring yang kurang maksimal merupakan bagian dari permasalahan orangtua peserta didik pada umumnya. Hal ini juga dilaporkan dalam penelitian Euis Kurniati, dkk (2020) dan Lilawati (2021) kesulitan yang di alami oleh orang tua terletak pada kurangnya pemahaman orang tua terhadap materi pembelajaran, minimnya waktu yang dimiliki oleh orang tua untuk mendampingi peserta didik belajar dirumah.

Selain itu, peran orangtua mengawasi anak ketika menggunakan smartphone. Hal ini untuk mencegah anak membuka konten negatif yang ada di media social. Selain itu juga orangtua memberikan dorongan kepada anak untuk menggunakan smartphone untuk hal hal yang positif, karena tidak semua aplikasi didalam smarphone negative tergantung anak dan orangtua memahami manfaat nya, seperti menggunakan aplikasi WA, tik tok, Zoom dalam menunjang belajar dan meningkatkan jiwa sosial. Hal ini senada dengan Penelitian Andriani (2021) bahwa kebutuhan penggunaan tik-tok dapat mempererat persahabatan sebagai tujuan bermain Tik-Tok adalah cara anak memenuhi kebutuhan kasih sayang dengan teman.

\section{PENUTUP}

Berdasarkan hasil penelitian yang dilakukan oleh peneliti dapat disimpulkan bahwa orang tua peserta didik kelas V SD Islam Nurul Iiihsan Palangkaraya mengalami kesulitan dalam mendampingi peserta didik belajar dirumah pada masa pandemi covid-19. Faktor-faktor yang dialami oleh orang tua dalam mendampini peserta didik belajar yaitu minimnya waktu yang dimiliki orang tua untuk mendampingi dan mengawasi peserta didik, kurangnya komunikasi antara orang tua dan peserta didik, orang tua kurang mampu memberikan motivasi dan keterbatasan waktu yang dimilikki oleh orang tua hingga tidak mampu mendampingi pesera didik pada saat proses pembelajaran hal ini membuat para orang tua kesulitan mengarahkan dan menjadi contoh ketika peserta didik mendapat tugas dari sekolah. Sedangkan faktor dari luar. sedangkan faktor dari luar yaitu, penjelasan guru terhadap materi masih kurang maksimal. Faktorfaktor inilah yang membuat orang tua menjadi kesulitan dalam menyelesaikan peran dan tanggung jawabnya sebagai orang tua. Rekomendasi dari penelitian adalah adalah Guru dan kepala Sekolah hendaknya membekali orang tua untuk mendampingi belajar anak di rumah melalui kegiatan pelatihan pendampingan pembelajaran daring bagi orangtua.

\section{REFERENSI}

Andriani, M.W. (2021). Studi Fenomenologi Motivasi Kebutuhan Penggunaan TikTok Dalam Perkembangan Kematangan Sosial Siswa Sekolah Dasar. Jurnal Bimbingan dan Konseling Ar-Rahman, $7(1)$.

Hero, Hermus, dan Maria. (2018). Peran Orangtua dalam meningkatkan motivasi belajar siswa kelas V di Sekolah dasar Inpres II legetang" Jurnal Riset Pendidikan Dasar, 1(2).

Irhamna (2016) Analisis Tentang Kendalakendala Yang di Hadapi Orang Tua Dalam Pembinaan Akhlak Dan Kedisiplinan Siswa Madrasah Darusalam. aL Bahtsu, 1(1).

Kurniati, E., Dkk, (2021). Analisis Peran Orang Tua Dalam Mendampini Anak di Masa Pandemi Covid-19. Jurnal Pendidikan Anak Usia Dini, 5 (1).

Muthmainnah, (2012). Peran Orang Tua dalam Menumbuhkan Pribadi Anak yang Androgynius Melalui Kegiatan Bermain. Jurnal Pendidikan Anak, 11 (1).

Nurkholis, I. (2021). Analisis Kelebihan dan Kekurangan dalam Pembelajaran Daring di SDN Pesanggrahan 01 Kota Batu Malang. Jurnal PTK, 2(1).

Rukaesih A. Maolani dan Ucu Cahyana, (2015). Metodologi Penelitian Pendiidkan. Jakarta Raja Grafindo Persada

Sugiyono, (2019). Metode Penelitian Pendekatan Kuantitatif, Kualitatif, dan $R \& D$. Bandung: Alfabeta

Wardani, A., \& Ayriza, Y. (2021). Analisis Kendala Orang Tua dalam Mendampingi Anak Belajar di Rumah Pada Masa Pandemi Covid-19. Jurnal Pendidikan Anak Usia Dini, 5 (1). 